\title{
Dividend Announcements of Banking Sector in Gulf Area; Pre, During and Post the Recent Global Financial Crisis
}

\author{
Bassam Jaara ${ }^{1}$ \& Mahmoud Dalou ${ }^{2}$ \\ ${ }^{1}$ Business school, Al-Ahliyya Amman University, Amman, Jordan \\ ${ }^{2}$ Buisness schoool, Coventry University, Coventry, United Kingdom \\ Correspondence: Bassam Jaara, Business school, Al-Ahliyya Amman University, Amman, Jordan, 19328, \\ Amman, Jordan. Tel: 962-5350-0211. E-mail: b.jaara@ammanu.edu.jo
}

Received: December 10, 2017

Accepted: April 13, 2018

Online Published: April 25, 2018

doi:10.5539/ijef.v10n6p20

URL: https://doi.org/10.5539/ijef.v10n6p20

\begin{abstract}
This research aims to analyze the movement of dividend policy announcements impact on share prices, and the performance of all listed banks in Gulf area pre-during-post the financial crisis. This research has positioned and utilized event study method, and dividend pay-out ratio to evaluate the movements in share prices of two event windows for 65 banks (All listed banks) from 2005 to 2013. The main results for this research showed that there is a strong signaling effect since most of the windows show positive impact of dividend announcements on the CAARS. Likewise, there can be equally significant lifecycle impact since the large banks show different pay out pattern as compared with the small banks. Moreover, there has been steady dividend pay by banks at an average even in the crisis periods. In addition, a proportion of payers have increased as compared to the non-payers over years, which is related to both life cycle and competition theories. The last finding presents that banking sector in the GCC countries have not been affected like other emerging countries during the global financial crisis, because they supported by oil prices.
\end{abstract}

Keywords: dividend announcement, emerging markets, dividend policy, dividend pay-out

\section{Background}

During the last few decades, a large number of previous academic studies have discussed and provided the effect of dividend announcements on share price. Dividend theories provided significant theory and empirical studies about this issue in different countries with different stock exchange markets. However, all these studies did not accept and approve a common view for it. The central concern for the economist, especially the financial economist, was the corporate dividend policy impact on the firm value, shareholder's wealth and the presence of ideal corporate dividend policy.

In dividend scholarships, Lintner (1956) was the leader for the examination between dividend policy and firm value. He provided that dividend policies under imperfect capital market conditions play an essential role in the decision making for management and shareholders wealth. In addition, the author introduced that fluctuation in corporate dividend policies may transfer some data to financial markets about the future and current financial position of the firm. In this regard, the idea of information asymmetries between investors and managers was introduced. Hence, the researcher reported positive market reaction (stock prices) to the increase in distributed amount of dividends for shareholders and vice versa with the decrease in dividends amount. Many researchers, such as Walter (1956) and Gordon (1962), obtained the same findings of Lintner (1956) about the market reaction to dividend announcement.

Miller and Modigliani (1961) criticized the previous discussion, and ignored the impact of dividend policy on firm value and shareholders wealth because they supported the assumption of perfect capital markets with perfect conditions (no tax, no transaction cost). They illustrated that managers may effect on the firm value by just changing the investment policies.

The third and last group of researchers, Brennan (1970), Brennan and Thakor (1990), introduced a combination between the findings of Lintner (1956) and Miller and Modigliani (1961). They presented that corporate dividend policy is related to the value of corporation, but at the same time, it is also critical. Moreover, this group of researchers presented the tax effect and the impact of it on share price: with high dividend payment with the 
existence of tax, the share price will move negatively and vice versa. Brennan and Thakor (1990) reported two main preferences for investors: when the distributions were small, they preferred dividend payment; nonetheless, if the dividend was large, they prefer to invest in repurchase agreements. This point reinforced that tax has a significant impact on stock prices in stock exchange markets.

The main purpose for this research is to examine the share price reaction to the dividend announcements of all listed banks in the Gulf area pre, during and post the financial crisis in 2007. The classical event study was used as a methodology to find the abnormal return for stock prices in these banks during a specific period $(-5,+5),(-3$, $+3),(-1,+1)$ before and after event day (announcement day). The selection of event study was based on previous researches such as that of Asimakopoulos et al. (2008) and Dasilas et al. (2008). This research will be more accurate than other researches because, it positioned different methods in the analysis for full sample.

Consequently, this research investigates the share price reaction to the dividend announcements of all the listed banks in the GCC region. To this end, the following section presents some important theoretical and empirical findings in the dividend world; all these findings are based on many theories such as, tax hypothesis, cash flow hypothesis and signaling theory. In the same regard, the methodology section simplify the data collection, the methodology, and the using of event study from several points of views. In addition, the analysis section discuss the results and present the impact of dividend announcements on CAAR for whole sample, paid vs. unpaid banks, increase vs. decrease DPS and large vs. small banks. After that, it will discuss the impact of financial crisis on DPS and link the findings with the stock indices and GDP of economy in GCC. In addition, this part is supported with many charts to simplify the impact of financial crisis on GCC. At the end, all these results will conclude in some points.

\section{Literature Review}

\subsection{Background}

A large number of previous academic studies have been adopted in the literature of the impact of dividend announcements on stock returns of organizations. Miller and Modigliani (1961) reported that dividends do not have an impact on the firm value under perfect capital markets conditions. Alternatively, they supported that the corporate value of the company could be affected by the investment policy. Subsequently, many researchers discussed the dividend puzzle to examine the influence of dividend distribution on the value of firms. The first justification to the decision of dividend distribution is founded in imperfect markets as a result of information asymmetries. Furthermore, many research studies provided the reaction of the market to the change in dividend announcements.

However, there is a significant difference in dividend policy between developed and developing markets. According to Kumar (1999), firms in emerging markets are recently oriented, less efficient in information and highly fluctuate with smaller size compared to developed markets. Nevertheless, the emerging markets are still lacking sufficient studies, especially in the Gulf Cooperation Council (GCC). Therefore, it is essential and valuable to study the dividend policy in GCC states to afford extra proof about dividend policy in these markets.

The GCC states are a set of six main countries: Saudi Arabia, Qatar, United Arab Emirates, Bahrain and Oman. These are known as six Arab oil-exporting countries. The GCC established in May 1981. The GCC became one common market (financial capital and commodities) and they adopted one common trading policy for foreign trading. Even with the strong commitment among the states, after two decades the GCC growth and achievements slowed, because at that time the main concentration for governments was on financial deficit and on security.

Actually, the situation in the GCC states reports some remarkable features that are different from other countries and relevant to the case study for dividend policy. Firstly, the situation in the GCC states is quite different from others because there is no tax on dividend or on capital gains. Secondly, the volatility in the stock exchange for these countries is too high and involves a specific level in the terms of information asymmetry, with high expectation for the agency cost. Thirdly, the governments own the major portion of listed firms, especially large firms. Therefore, it is quite interesting to examine and analyze this area.

\subsection{Theories of Dividend Policies}

\subsubsection{Dividend Irrelevance Hypothesis}

Miller and Modigliani (1958) completed the first discussion about dividend irrelevance hypothesis; that discussion was based on the efficient market hypothesis. This hypothesis debates that there is no information asymmetry between the managers (inside) of the firms and the shareholders (outside). In addition, there is no transaction cost and the firm value is independent from its financial structure. In the wider context, under this 
debate the focal is only on the investing in positive NPV projects regardless of the method of financing (debt or equity), or if they announced for dividend or not. Because of this hypothesis, the dividend payment is irrelevant to the market valuation of the firm.

\subsubsection{Cash Flow Hypothesis}

Lang and Litzenberger (1989) reported the free cash flow hypothesis. The theory illustrated the main target from dividend payment for a shareholder is to avoid the unnecessary actions by managers that are related to their own benefit. The managers usually show a trend of using the free cash flow to increase the size of the firm rather than investment in profitable projects. Shareholders also prefer the increasing of dividend to reduce the available free cash flow to managers. Therefore, the stock prices respond positively to the increase in dividend announcement and negatively to its decrease by over investors.

\subsubsection{Tax Hypothesis}

Moving to the tax hypothesis, DeAnglo and Masulis (1980) present the relationship between dividend payment and tax theory. The investors prefer high dividend payment when they are at low tax brackets and vice versa. An earlier study done by Miller and Scholes (1982) criticized the tax effect indirectly because of the high attention to the definition of dividends. They failed in their research to find the link between the tax existence and dividend preferences. However, several recent research such as Chaplinsky and Seyhun (1990), Sterk and Vandenbery (1990), mentioned that the investors may rely not only on the taxes, but that there are some other essential issues that should be taken into consideration.

\subsubsection{Agency Cost Theory}

The agency cost theory is considered to be as one of the most important theories in the dividend puzzle. Jensen and Meckling (1978) report the firms with high managerial ownership have low agency costs because the manager and shareholder have the same goals. Furthermore, Shleifer and Vishney (1986) illustrate the firms with large numbers of shareholders have better ability to control the managerial activities. The main cause for agency problem is information asymmetry.

Barnea, Haugen, and Senbet (1981) present that agency problem is transfer of the wealth from bondholders to shareholders, through getting high risk and return projects by directors, and the failure to accept the projects with positive net present value and incentive consumption in excess of consumed levels by corporate managers. Furthermore, this gap could also happen between the government and other managers, when managers look for their benefits from the obtainable resources to the firm, which could help them to raise their salaries and take advantage of other expenses. Therefore, to avoid the double agency problems, several firms have adopted high dividend payouts.

\subsubsection{Financial Lifecycle Model}

Grullon et al. (2002) examined numerous aspects in dividend policy, which they emphasized with a focus on life cycle theory. They examined the relationship between the dividend pay-out and the position of the firm in the life cycle. They found that some firms declined in the life cycle after increasing the dividend pay-out, but they reported that some firms show a trend to recover after dividend decreasing. Hence, the results for this research arguing the results of signaling hypothesis.

\subsubsection{Information Signaling Theory}

The signaling theory is linked to all previous theories, because it is focusing on the reaction of the stock markets to the movements of dividends. Chemmanur et al. (2010) report that dividend signaling theory considers the dividend as signal of a management's prospects about the profit in the future, and the response of share prices. They reported that the share prices are linked positively to the increase in dividend and vice versa. Bhattacharya (1979) mentioned that the usage of dividend as a signalling tool is linked to some costs. For instance, the future prospects by using the dividend as a signal may incur transaction costs related with locating external financing. In addition, Miller and Rock (1985) reported another cost linked to signalling by using dividend, which is called the distortion of a firm's investment decisions.

\subsection{Empirical Evidence on the Dividend Theories}

There are several studies on the topic of dividend policy. This part will present some relevant empirical studies in developed and emerging countries related to the dividend theories. In the United States of America, Petit (1972) confirmed that signaling hypothesis occurs and price of securities responds to the movement in dividend pay-out. Furthermore, some studies are consistent with the findings of Petit (1972) such as Kothari and Ball (1991).

Michaely et al. (1995) and Ryan et al. (2000) studied the dividend omission and initiation impact on the investors 
(earnings surprises for investors). The sample for the research of Michaely et al. (1995) was 887 dividend omissions and 561 cash dividend initiations between 1964 and 1988. The result validated signalling hypothesis as he reported $7 \%$ decline in the share price as a result of dividend omission, and 3\% increase in share price caused by dividend initiation. Furthermore, Ryan et al. (2000) obtained similar results and illustrated that signalling hypothesis has a bigger impact on share price than free cash flow hypothesis.

Moreover, Iqbal et al. (2014) examined the effect of dividend announcement on stock prices in banking industry of Pakistan, during the period 2088-2012. The descriptive statistics and regression analysis represent that there is positive or negative relationship has been found between the dividend and stock price. It is proved that the dividend has positive regression with the earning per share and negative regression dividend with the stock price

Hussainey et al. (2011) tried to confirm the Hussainey and Walker (2009) results by choosing firms without dividend payments. Their research found that sectors with great growth and low disclosure of information do not pay dividends, with no change in share prices and vice versa. Nevertheless, for companies with high growth and disclosure of information, they noticed that share price might change.

Dewi (2011) had an identical view with Jais et al. (2010) to study the signaling effect in Indonesia, and used a sample of 415 companies listed on the Indonesian Stock Exchange market for the 4 years between 2006 and 2010. The ordinary least square was used to calculate the abnormal return in the event window. In addition, this study supported the signaling effect only with the increase in dividend, but with the decrease in dividend, the results were negative. The reason behind this is that in this kind of research the OLS regression cannot test the outcomes of firm size and the yield of dividend. For positive results, the OLS regression is identified for pre cumulative abnormal return.

In another line of research, Kurniasih et al. (2011) examined 61 Indonesian companies for the 5 years between 2004 and 2009. In his study, he observed all dividends declared companies over this period; they documented positive returns before and after the day of announcement by four days. For constant payment, the research presented fixed level in share prices, without any movement. For decrease payment, they noticed abnormal return of $-2.06 \%$ before and after the announcement by four days.

In India, there are some studies, which discuss the link between the dividends and stock prices. Taneem and Yuce (2011) examined the signaling theory in India and reported that some companies with increase in dividend achieved greater AAR and CAAR, which reinforces and supports the efficiency of the market.

In addition, Manneh and Naser (2015) examined the relationship between dividend policy and the attributes of non-financial companies listed on Abu Dhabi Securities Exchange (ADX) over the period 2010-2012. The result of the analysis revealed that dividend policy is positively and significantly associated with corporate profitability, risk, free cash flows, size, majority shareholders and industry. Dividend policy, however, appeared to be negatively and significantly associated with corporate level of leverage. The result supports agency theory.

In the GCC countries there are many researches reporting empirical studies about the banking sector in the Gulf area. Iqbal (2007) presented the differences in the performance between conventional and Islamic banks. Other study done by Ariss (2010) presented the financial consistency among different types of banks in the Gulf area. In addition, Hasan and Dridi (2010) analyzed the effect of the financial crisis on the banking sector in the Gulf area. Uddin and osman (2008) examined the effect of dividend announcement on share price was examined only by one research in Saudi Arabia. in their research, they reported on 28 firms ( 8 of them banks) between 2001 and 2005 , and found that investors are exposed to loss after the announcement by $2.2 \%$, and reported that the increase in dividend announcement does not mean that the available information is efficient and vice versa.

However, most studies are concentrated on developed markets more than emerging markets, which are not probably examined, with the knowledge that there is massive potential in these areas to analyze the effect of dividend policy on shareholders wealth. In addition, there are few researches that have been done on banks; there is no study which discusses the whole Gulf area as one sample, the vast majority of researches being focused on specific countries. Therefore, this study may examine and explain unexplored issues in the dividend announcements for this area.

\section{Methodology}

\subsection{Methodology and Data Collection}

The purpose of this paper is to find if the dividend signalling theory is truly held. The theory will present the results from the effect of dividend announcement on stock price. This will test the movement in stock prices with the movement in dividend announcement, as the dividend may hold some information that causes the movement in share price. When there is no information the stock price should stay constant without any change. 
To reach the target, the analysis will discuss the market reaction for dividend announcement; it will done by taking 105, 103 and 101 working days from announcement data in the whole of the Gulf area markets. In the analysis model, a null hypothesis will exist when there is no reaction from market with the movement of dividend.

H0: The change in dividend does not have any statically significant impact on share price volatility, and any abnormal returns linked to dividend announcement are the outcome of chance.

H1: The changes in dividend have significant effect on share price volatility, and any abnormal return is linked to dividend announcement and is the result of many factors, not by chance.

The data was gathered for market index and share price from bankers' magazines, Yahoo Finance and Reuters Eikon. Furthermore, these sources provided some other information for this paper such as announcement day, ex-date dividend, payment methods, record date, and amount paid and SICS code.

\subsection{Event Study Methodology}

To achieve the aim of this research, this paper will present three event windows. The first window will be 11 ( -5 , $0,+5)$ trading days, the second window will be $7(-3,0,+3)$ days and the last window will be $3(-1,0,1)$ trading days. The $(-5,-3,-1)$ days before the event day is well-known as the pre-event window, and the $(+5,+3,+1)$ days after the event day is called the post-event window. Also, the periods between $(+5,-105),(+3,-103),(+1,-101)$ days is known as the estimation period. The figure below shows the event window as discussed in many researches.

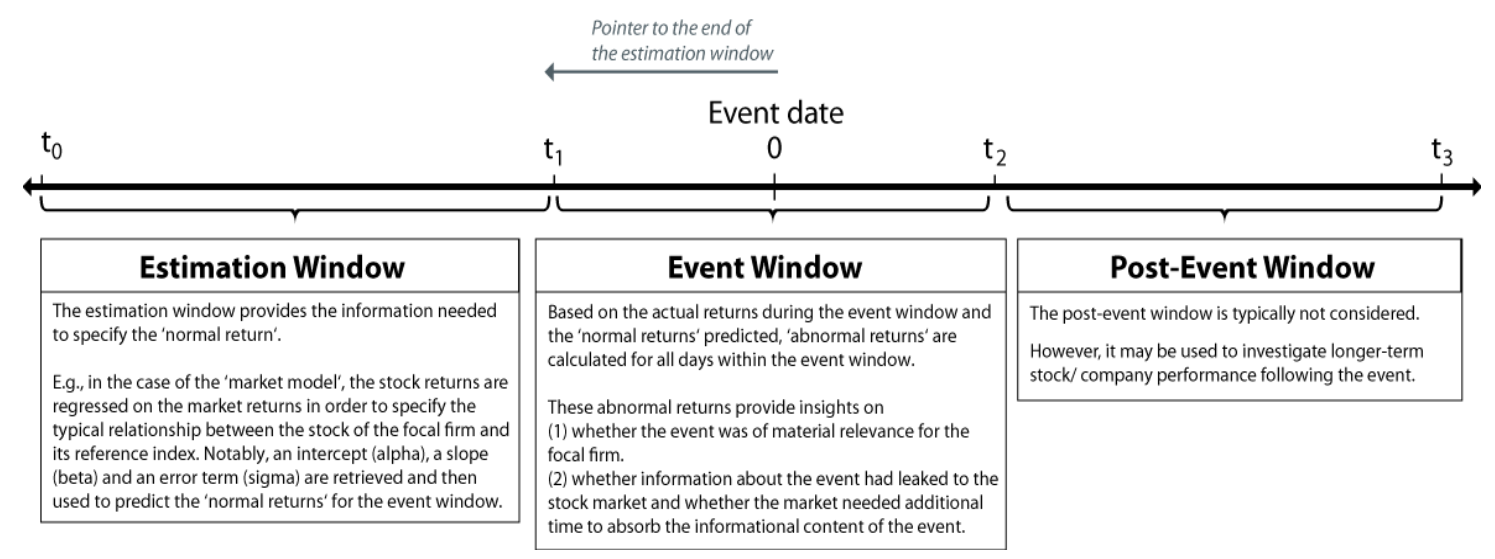

Figure 1. Event window

To estimate the abnormal return, we might discuss two important issues, the first one is the average of abnormal return and the second one is the cumulative abnormal return. The movements in stock returns are reflected by many particular factors in the markets, but the main idea from using event study is to find what exact part of price movement (stock return) is affected by the specific event of interest. Therefore, all these movements at the specific event could indicate to the idea of abnormal returns. For further explanation, the calculation for abnormal return of stock in the firm is based on deducting the expected return (without event effect) from the actual return for that firm in the event period as the following formula:

$$
A R_{f}=R_{a}-\mathrm{ER}_{f}
$$

Where:

$A R_{f}$ : The abnormal return of the firm.

$R_{a}$ : The actual return in the event period.

$\mathrm{ER}_{f}$ : The expected return without event impact for the firm.

Moreover, the calculation for market model with consideration of security returns to the return of market portfolio is as the following formula:

$$
R_{a}=\alpha f+\beta R_{m}
$$

Where:

$R_{a}$ : The actual return in the event period.

$\alpha \mathrm{f}$ : The constant term of the stock in the firm. 
$\beta$ : The market beta of the stock.

$R_{m}$ : The market returns.

Furthermore, all these parameters are estimated by time series data in the estimation period which leads to the individual announcement (100 working days). After that the estimation period is used to evaluate the daily abnormal return in the events window. Hence, the daily abnormal return is measured from the actual return for the event period and estimated coefficient period as the following equation (combining the 2 above formulas):

Where:

$$
A R_{f t}=R_{f}-\left(\alpha f+\beta R_{m}\right)
$$

$A R_{f t}$ : The abnormal return of firm $\mathrm{f}$ to the day.

Then, by using the event window, the calculation of average abnormal return could be as the following equation:

$$
A A R_{f t}=\frac{1}{N} \sum_{i=1}^{N} A R_{f t}
$$

Where:

$\mathrm{N}$ : the number of firms.

In addition, the cumulative abnormal return differs from the average abnormal return because it is starting at day $\mathrm{T}$ and finishing at day $\mathrm{T} 2$. It could be calculated as the following formula:

$$
\operatorname{CAR}\left(t_{1}, t_{2}\right)=\frac{1}{N} \sum_{t_{2}}^{t_{1}} A A R_{f t}
$$

Moreover, for the event period:

$$
\operatorname{CAAR}\left(t_{1}, t_{2}\right)=\frac{1}{N} \sum_{i=1}^{N} C A R_{f t}
$$

Moreover, to find the significance of the results ( $\mathrm{S}$ ):

$$
t=\frac{C A A R}{S(C A A R)}
$$

Where,

$$
S(C A A R)=\left[\frac{1}{N} \sum_{i=1}^{N}\left(C A R_{f t}-C A A R_{f t}\right)^{2}\right]^{-1 / 2}
$$

For the second target in this dissertation, the dividend payout ratio should be applied to find the effect of financial crisis on the dividend policy.

\subsection{Event Study Process}

The figure below shows the process of analysing the data by using event study methodology:

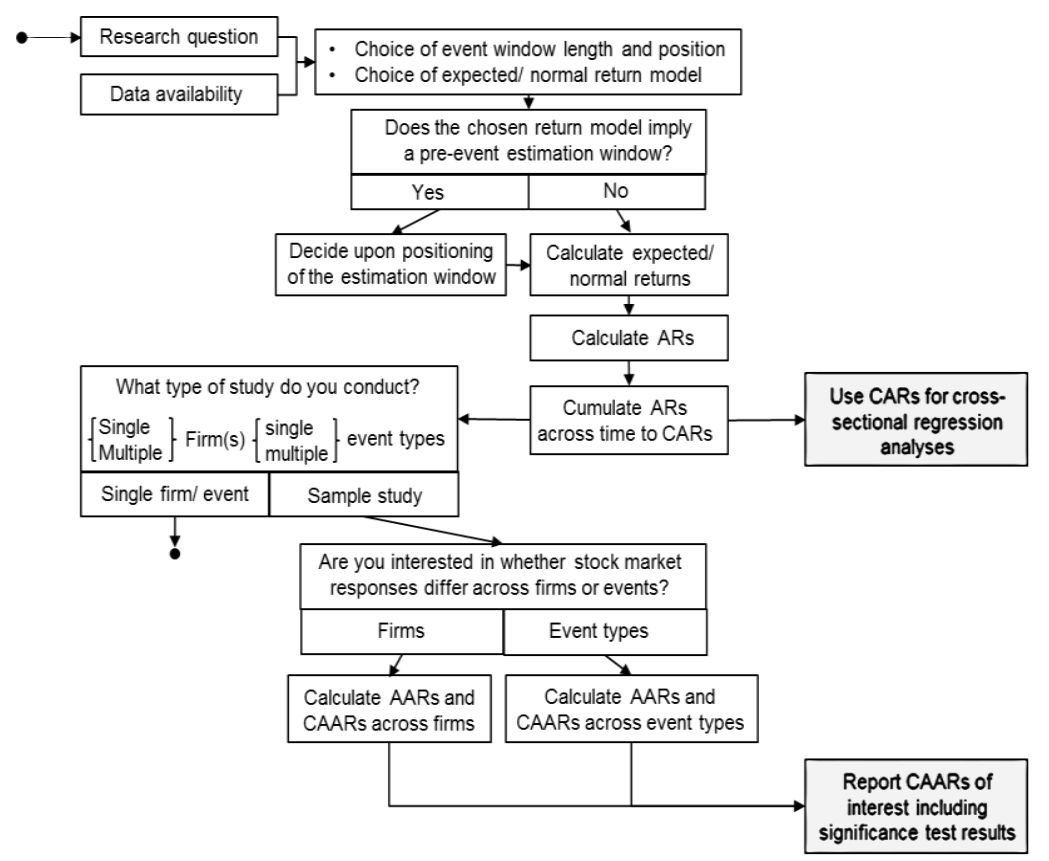

Figure 2. Event study process 


\section{Data Analysis}

\subsection{Impact of Dividend Announcements on the Caars (Whole Sample)}

Table 1. CAARs: whole sample

\begin{tabular}{|c|c|c|c|c|c|}
\hline & CAAR & Std. Error of Mean & $\mathrm{N}$ & t-value & Sign. \\
\hline \multicolumn{6}{|c|}{ Event Window $(-5,+5)$} \\
\hline 5 & $0.527 \%$ & .0040 & 480 & 1.331 & .184 \\
\hline 4 & $0.441 \%$ & .0038 & 480 & 1.149 & .251 \\
\hline 3 & $0.370 \%$ & .0036 & 480 & 1.031 & .303 \\
\hline 2 & $0.203 \%$ & .0036 & 480 & .557 & .578 \\
\hline 1 & $0.399 \%$ & .0034 & 480 & 1.191 & .234 \\
\hline 0 & $0.229 \%$ & .0030 & 480 & .761 & .447 \\
\hline-1 & $0.139 \%$ & .0027 & 480 & .520 & .603 \\
\hline-2 & $-0.033 \%$ & .0023 & 480 & -.144 & .885 \\
\hline-3 & $-0.019 \%$ & .0018 & 480 & -.105 & .916 \\
\hline-4 & $-0.025 \%$ & .0015 & 480 & -.172 & .864 \\
\hline-5 & $-0.097 \%$ & .0010 & 480 & -.925 & .355 \\
\hline \multicolumn{6}{|c|}{ Event Window $(-3,+3)$} \\
\hline 3 & $0.444 \%$ & .0032 & 480 & 1.404 & .161 \\
\hline 2 & $0.273 \%$ & .0032 & 480 & .858 & .391 \\
\hline 1 & $0.455 \%$ & .0030 & 480 & 1.542 & .124 \\
\hline 0 & $0.290 \%$ & .0026 & 480 & 1.126 & .261 \\
\hline-1 & $0.143 \%$ & .0021 & 480 & .689 & .491 \\
\hline-2 & $-0.038 \%$ & .0017 & 480 & -.226 & .821 \\
\hline-3 & $0.008 \%$ & .0011 & 480 & .075 & .940 \\
\hline \multicolumn{6}{|c|}{ Event Window $(-1,+1)$} \\
\hline 1 & $0.515 \%$ & .0024 & 480 & 2.175 & $.030 * *$ \\
\hline 0 & $0.328 \%$ & .0019 & 480 & 1.741 & $.082 *$ \\
\hline-1 & $0.138 \%$ & .0011 & 480 & 1.236 & .217 \\
\hline
\end{tabular}

Note. $* * *$ Significant at $1 \%$, ** Significant at $5 \%$. Significant at $10 \%$.

The above table shows the impact of the dividend announcement on the CAAR and this test was carried out for several windows to check robustness, however, the impact of the dividend announcement is ambiguous on the returns since there are significant $t$ values for positive returns and with most of the insignificant returns too. $T$ values are calculated as the ratio of the coefficients and the standard errors, which is then compared to the critical values at the forgiven degrees of freedom and given significance levels. However, if the former is greater than the later, then the null hypothesis that the coefficient is equal to 0 is rejected, which again means that there are significant impacts of the dividend announcements on the returns. Significance level drops as the window lengths are increased considerably. There are various models to calculate the cumulative abnormal returns and here a standard market model is followed.

For the short window $(-1,+1)$, the CAAR on the announcement day is positive $(0.328 \%)$ and significant at $10 \%$ level. In addition, the CAAR one day after the announcement is positive $(0.515 \%)$ and significant at $5 \%$ level. On the other hand, for the long window the CAARs are negative prior to the dividend announcements and steadily become positive after the announcements till the end of the window length $(-5,+5)$; this might indicate signalling which has to be tested further. However, the CAAR on the announcements day is positive $(0.229 \%)$, but insignificant. Costly signalling holds that dividend payouts have a positive impact on the return measures since the market participants are able to distinguish between the good and bad firms, and this rewards the firms with higher prospects in future (Miller \& Rock, 1985).

In addition, there are contending theories too, and one such is the life cycle theory that suggests that dividend payouts should change over the financial life cycle of a firm, and increase with the maturity of firms (Grullon et al., 2002). Hence, the results are difficult to interpret solely from the perspective of signalling theory. There are certainly implications of tax regime too, and specifically these economies enjoy a free tax regime. However, announcement effects are typical as with other event studies, since it can be observed that as the window length shortens the impact becomes stronger and it is highest when the length is just 1 day.

One important challenge for event studies is to separate the impact of similar other events; this might have some 
significant impact in the current case too. Another important trend that is observed among many firms is known as dividend smoothing, or partial adjustment of pay-outs, which means that firms have some target dividends set which depend on some firm specific factors, and then the firms slowly adjust their dividends towards the target. In the above table we find that the changes in CAARs due to dividend announcements are not abrupt in nature, rather the announcement effect smooths out over some period of time; this may be due to the fact that banks are following a steady dividend payout policy rather than random payouts, which is again well expected by the market participants. The above table may also hint of the behavioral aspects of the investors. Whereby, the tax regime is free in most of these economies, it is expected that the investors will prefer capital appreciation rather than dividend payouts. However, in the results there is a strong clientele effect that shows that investors prefer to hold dividends irrespective of whether there is capital appreciation or not (Chaplinsky \& Seyhun, 1990).

\subsection{Impact of Dividend Announcements on the CAARs (Paid vs. Un-Paid Banks)}

Table 2. CAARs: Paid vs. Un-Paid banks

\begin{tabular}{|c|c|c|c|c|c|c|c|c|c|c|}
\hline & \multicolumn{5}{|c|}{ NOPAY } & \multicolumn{5}{|c|}{ PAY } \\
\hline & CAAR & Std. Error of Mean & $\mathrm{N}$ & $\mathrm{t}$-value & Sign. & CAAR & Std. Error of Mean & $\mathrm{N}$ & t-value & Sign. \\
\hline \multicolumn{11}{|c|}{ Event Window $(-5,+5)$} \\
\hline 5 & $-2.463 \%$ & .0123 & 90 & -2.004 & $.048 * *$ & $1.217 \%$ & .0039 & 390 & 3.129 & $.002 * * *$ \\
\hline 4 & $-2.831 \%$ & .0118 & 90 & -2.403 & $.018 * *$ & $1.196 \%$ & .0038 & 390 & 3.176 & $.002 * * *$ \\
\hline 3 & $-3.129 \%$ & .0110 & 90 & -2.854 & $.005 * * *$ & $1.178 \%$ & .0035 & 390 & 3.358 & $.001 * * *$ \\
\hline 2 & $-3.869 \%$ & .0110 & 90 & -3.509 & $.001 * * *$ & $1.143 \%$ & .0035 & 390 & 3.230 & $.001 * * *$ \\
\hline 1 & $-2.958 \%$ & .0098 & 90 & -3.014 & $.003 * * *$ & $1.174 \%$ & .0033 & 390 & 3.521 & $.000 * * *$ \\
\hline 0 & $-2.875 \%$ & .0090 & 90 & -3.192 & $.002 * * *$ & $0.946 \%$ & .0030 & 390 & 3.192 & $.002 * * *$ \\
\hline-1 & $-2.668 \%$ & .0081 & 90 & -3.292 & $.001 * * *$ & $0.786 \%$ & .0026 & 390 & 3.035 & $.003 * * *$ \\
\hline-2 & $-2.174 \%$ & .0076 & 90 & -2.865 & $.005 * * *$ & $0.461 \%$ & .0022 & 390 & 2.115 & $.035 * *$ \\
\hline-3 & $-1.731 \%$ & .0056 & 90 & -3.095 & $.003 * * *$ & $0.376 \%$ & .0018 & 390 & 2.099 & $.037 * *$ \\
\hline-4 & $-0.978 \%$ & .0043 & 90 & -2.279 & $.025 * *$ & $0.195 \%$ & .0015 & 390 & 1.309 & .191 \\
\hline-5 & $-0.860 \%$ & .0029 & 90 & -2.942 & $.004 * * *$ & $0.079 \%$ & .0011 & 390 & .733 & .464 \\
\hline \multicolumn{11}{|c|}{ Event Window $(-1,+1)$} \\
\hline 3 & $-2.273 \%$ & .0081 & 90 & -2.795 & $.006 * * *$ & $1.070 \%$ & .0033 & 390 & 3.212 & $.001 * * *$ \\
\hline 2 & $-3.014 \%$ & .0078 & 90 & -3.842 & $.000 * * *$ & $1.031 \%$ & .0034 & 390 & 3.071 & $.002 * * *$ \\
\hline 1 & $-2.096 \%$ & .0070 & 90 & -2.982 & $.004 * * *$ & $1.044 \%$ & .0032 & 390 & 3.280 & $.001 * * *$ \\
\hline 0 & $-2.040 \%$ & .0061 & 90 & -3.361 & $.001 * * *$ & $0.827 \%$ & .0028 & 390 & 2.985 & $.003 * * *$ \\
\hline-1 & $-1.945 \%$ & .0051 & 90 & -3.817 & $.000 * * *$ & $0.625 \%$ & .0022 & 390 & 2.837 & $.005 * * *$ \\
\hline-2 & $-1.479 \%$ & .0047 & 90 & -3.131 & $.002 * * *$ & $0.295 \%$ & .0017 & 390 & 1.754 & $.080 *$ \\
\hline-3 & $-0.941 \%$ & .0031 & 90 & -2.990 & .004 & $0.227 \%$ & .0011 & 390 & 2.063 & $.040 *$ \\
\hline \multicolumn{11}{|c|}{ Event Window $(-1,+1)$} \\
\hline 1 & $-0.823 \%$ & .0057 & 90 & -1.4450 & .152 & $0.824 \%$ & .0026 & 390 & 3.1948 & $.002 * * *$ \\
\hline 0 & $-0.873 \%$ & .0047 & 90 & -1.8655 & $.065 *$ & $0.605 \%$ & .0020 & 390 & 2.9830 & $.003 * * *$ \\
\hline-1 & $-0.740 \%$ & .0029 & 90 & -2.5469 & $.013 * *$ & $0.341 \%$ & .0012 & 390 & 2.8932 & $.004 * * *$ \\
\hline
\end{tabular}

Note. *** Significant at $1 \%$, ** Significant at $5 \%$. * Significant at $10 \%$.

There is a strong theoretical, as well as empirical, suggestion that those firms which do not pay dividends or reduce dividends suffer negative response from the market relative to those which pay steady dividends. The above table captures the impact of the dividend announcements for payers' banks vs. non-payers' banks for various window lengths and results are quite as expected. The main results indicate that the CAARs are negative and significant when the dividends are 0 . In addition, this result can be more interesting since the chosen sector is bank, and there are arguments for a higher opaque nature of banks. Hence, there might be more intense necessity for the banks to signal solvency via dividend payouts, and hence when they decide not to pay the market participants respond negatively. These results are quite similar to the research of Ryan et al. (2000).

However, the response to the positive dividend payouts are not always significantly positive as seen in the earlier section, where here too the significance becomes stronger when the window lengths are shortened. It seems that there is an interaction impact between both the signalling and life cycle factors that has to be further clarified. Later, however, statistics will be provided which clarify that the proportion of payers has gone up considerably over the last decade, even in the times of financial crisis. There can be several factors responsible for this, which will be highlighted in the conclusion. Also, there can be several factors for not paying dividends at all, which are 
mainly related to the lifecycle factors, and if the industry itself is in the growth phase then most of the firms should follow a non-payer role since they need to plough back more to invest in good projects (Grullon et al., 2002). However, in later statistics we will see that the proportions of the payers have increased over time.

Another important observation is that the negative impact of 0 dividend payouts is significant over all lengths of windows, whereas the positive impacts fades with increase in the number of days. This again hints at the fact that investors consider 0 dividends/dividend cut as to be worse news than the increase in dividends; this behavior is again to be explained by other theories than signalling theory alone (Miller \& Rock, 1985).

The main challenge lies in the fact that dividends are driven by various factors and it is difficult to disentangle factors. In the banking sector the trend is for payers, i.e. most of the commercial banks do pay dividends, and at times large dividends, compared to the non-banking firms, whilst the case of banks is similar, and markets are quite sensitive about the payouts. The above economies are special in the sense that they have fundamentally different tax regime as compared to the developed economies, and even then, they have similar trends as in the developed markets. More specifically, tax-free regime would mean rational investors might consider capital appreciation preferable to the dividend gains. However, the above results clarifies that the dividend non-payers are punished and payers are rewarded.

\subsection{Impact of Dividend Announcements on the CAARs (Increase vs. Reducing DPS)}

Table 3. CAARs: Increase vs. Reducing DPS

\begin{tabular}{|c|c|c|c|c|c|c|c|c|c|}
\hline & \multicolumn{3}{|c|}{ Decrease DPS } & \multicolumn{3}{|c|}{ Increase DPS } & \multicolumn{3}{|c|}{ No Change } \\
\hline & CAAR & $\mathrm{N}$ & Sign. & CAAR & $\mathrm{N}$ & Sign. & CAAR & $\mathrm{N}$ & Sign. \\
\hline \multicolumn{10}{|c|}{ Event Window $(-5,+5)$} \\
\hline 5 & $-2.038 \%$ & 112 & $.017 * *$ & $2.759 \%$ & 222 & $.000 * * *$ & $0.829 \%$ & 51 & .278 \\
\hline 4 & $-1.990 \%$ & 112 & $.016 * *$ & $2.651 \%$ & 222 & $.000 * * *$ & $0.972 \%$ & 51 & .166 \\
\hline 3 & $-1.892 \%$ & 112 & $.011 * *$ & $2.579 \%$ & 222 & $.000 * * *$ & $0.994 \%$ & 51 & .137 \\
\hline 2 & $-1.964 \%$ & 112 & $.013 * *$ & $2.472 \%$ & 222 & $.000 * * *$ & $1.314 \%$ & 51 & $.038 * *$ \\
\hline 1 & $-2.078 \%$ & 112 & $.004 * * *$ & $2.601 \%$ & 222 & $.000 * * *$ & $1.221 \%$ & 51 & $.053 *$ \\
\hline 0 & $-2.219 \%$ & 112 & $.001 * * *$ & $2.410 \%$ & 222 & $.000 * * *$ & $0.692 \%$ & 51 & .205 \\
\hline-1 & $-1.493 \%$ & 112 & $.009 * * *$ & $1.871 \%$ & 222 & $.000 * * *$ & $0.413 \%$ & 51 & .447 \\
\hline-2 & $-1.199 \%$ & 112 & $.018 * *$ & $1.252 \%$ & 222 & $.000 * * *$ & $-0.022 \%$ & 51 & .956 \\
\hline-3 & $-0.574 \%$ & 112 & .184 & $0.779 \%$ & 222 & $.000 * * *$ & $0.208 \%$ & 51 & .503 \\
\hline-4 & $-0.433 \%$ & 112 & .197 & $0.492 \%$ & 222 & $.009 * * *$ & $0.048 \%$ & 51 & .849 \\
\hline-5 & $-0.610 \%$ & 112 & $.009 * * *$ & $0.407 \%$ & 222 & $.002 * * *$ & $0.207 \%$ & 51 & .345 \\
\hline \multicolumn{10}{|c|}{ Event Window $(-1,+1)$} \\
\hline 3 & $-1.466 \%$ & 112 & $.038 * *$ & $2.233 \%$ & 222 & $.000 * * *$ & $1.016 \%$ & 51 & $.097 *$ \\
\hline 2 & $-1.550 \%$ & 112 & $.040 * *$ & $2.126 \%$ & 222 & $.000 * * *$ & $1.327 \%$ & 51 & $.020 * *$ \\
\hline 1 & $-1.673 \%$ & 112 & $.016 * *$ & $2.230 \%$ & 222 & $.000 * * *$ & $1.223 \%$ & 51 & $.032 * *$ \\
\hline 0 & $-1.820 \%$ & 112 & $.003 * * *$ & $2.061 \%$ & 222 & $.000 * * *$ & $0.689 \%$ & 51 & .142 \\
\hline-1 & $-1.090 \%$ & 112 & $.022 * *$ & $1.444 \%$ & 222 & $.000 * * *$ & $0.410 \%$ & 51 & .376 \\
\hline-2 & $-0.796 \%$ & 112 & $.026 * *$ & $0.821 \%$ & 222 & $.000 * * *$ & $-0.042 \%$ & 51 & .876 \\
\hline-3 & $-0.181 \%$ & 112 & .454 & $0.385 \%$ & 222 & $.005 * * *$ & $0.175 \%$ & 51 & .378 \\
\hline \multicolumn{10}{|c|}{ Event Window $(-1,+1)$} \\
\hline 1 & $-0.850 \%$ & 112 & .116 & $1.533 \%$ & 222 & $.000 * * *$ & $1.284 \%$ & 51 & $.012 * *$ \\
\hline 0 & $-1.017 \%$ & 112 & $.020 * *$ & $1.369 \%$ & 222 & $.000 * * *$ & $0.744 \%$ & 51 & $.048 * *$ \\
\hline-1 & $-0.321 \%$ & 112 & .226 & $0.656 \%$ & 222 & $.000 * * *$ & $0.460 \%$ & 51 & .164 \\
\hline
\end{tabular}

Note. *** Significant at $1 \%, * *$ Significant at $5 \%$. * Significant at $10 \%$.

Another standard way in the literature to measure the impact of dividend signalling is to test the impact of increase or decrease of dividend payouts on the CAARs, where increase should mean good signal under information asymmetry. Both increase and decrease of payouts may send signals to the market; good news can be conveyed through increase in dividends, whereas cut back in payouts/no payout at all can signal bad news. These findings are identical to Balachandran et al. (2004) research in Australia, which discussed earlier in empirical studies.

In addition, the above table on average responds negatively to the dividend cuts. There is a clear negative significant impact on the CAARs for decrease in dividends, and positive impact for the increase in dividends. Comparing the impacts it is clear that decrease in dividends are taken as to be worse news than increase in 
dividends since the former impact is always more significant, and this can't be explained by signalling theory only as there can be various behavioral as well as life cycle factors motivating such results. Importantly, behavioral theories (Shiller, 2012) maintain that investors do not want to witness cut in dividends, and even for irrational reasons consider that to be bad news and respond negatively, whereas the life cycle theory suggests that there can be greater reinvestment during greater investment opportunities, hence cut in dividends.

If the rational investors realize that reinvestment is needed then they may not respond negatively, however, this is not the indication of the above results. Therefore, behavioral factors may be more significant in this case, along with signalling impact. Later a robust regression model can be built upon the basic findings to analyze these auxiliary impacts. Another more realistic analysis is the partial adjustment of dividends, where there are targets set by the firms, which again depends on various firm specific parameters, and the firms adjust these (both increase and decrease) accordingly. The above results might also reflect the adjustment process, but again the market seems to have always considered cutting dividends as bad news. Hence, overall the results hint at signalling theory. These results are partially similar to Jais et al. (2010) research in Indonesia.

4.4 Impact of Dividend Announcements on the Caars (Large vs. Small Banks According to the Median and Mean)

Table 4. CAARs: Large vs. Small banks (Median and Mean)

\begin{tabular}{|c|c|c|c|c|c|c|c|c|}
\hline & \multicolumn{4}{|c|}{ Median 14,956M \$ } & \multicolumn{4}{|c|}{ Mean: 24,709 M \$ } \\
\hline & \multicolumn{2}{|c|}{ Large $(\mathrm{TA}>14,956 \mathrm{M} \$)$} & \multicolumn{2}{|c|}{ Small $(\mathrm{TA}<=14,956 \mathrm{M} \$)$} & \multicolumn{2}{|c|}{ Large $(\mathrm{TA}>24,709 \mathrm{M} \$)$} & \multicolumn{2}{|c|}{ Small $(\mathrm{TA}<=24,709 \mathrm{M} \$)$} \\
\hline & CAAR & Sign. & CAAR & Sign. & CAAR & Sign. & CAAR & Sign. \\
\hline \multicolumn{9}{|c|}{ Event Window $(-5,+5)$} \\
\hline 5 & $1.099 \%$ & $.006 * * *$ & $-0.302 \%$ & .698 & $1.160 \%$ & $.007 * * *$ & $0.075 \%$ & .902 \\
\hline 4 & $1.033 \%$ & $.008 * * *$ & $-0.417 \%$ & .579 & $0.976 \%$ & $.018 * *$ & $0.058 \%$ & .922 \\
\hline 3 & $1.090 \%$ & $.003 * * *$ & $-0.673 \%$ & .335 & $1.024 \%$ & $.010 * * *$ & $-0.097 \%$ & .859 \\
\hline 2 & $0.863 \%$ & $.019 * *$ & $-0.753 \%$ & .295 & $0.851 \%$ & $.029 * *$ & $-0.259 \%$ & .644 \\
\hline 1 & $0.939 \%$ & $.009 * * *$ & $-0.384 \%$ & .547 & $0.915 \%$ & $.015 * *$ & $0.030 \%$ & .952 \\
\hline 0 & $0.770 \%$ & $.017 * *$ & $-0.554 \%$ & .333 & $0.931 \%$ & $.005 * * *$ & $-0.272 \%$ & .552 \\
\hline-1 & $0.487 \%$ & .103 & $-0.366 \%$ & .454 & $0.571 \%$ & $.074 *$ & $-0.170 \%$ & .667 \\
\hline-2 & $0.278 \%$ & .281 & $-0.485 \%$ & .255 & $0.378 \%$ & .164 & $-0.327 \%$ & .345 \\
\hline-3 & $0.199 \%$ & .334 & $-0.336 \%$ & .316 & $0.218 \%$ & .310 & $-0.189 \%$ & .492 \\
\hline-4 & $0.076 \%$ & .648 & $-0.172 \%$ & .517 & $-0.030 \%$ & .876 & $-0.022 \%$ & .918 \\
\hline-5 & $0.064 \%$ & .564 & $-0.330 \%$ & .100 & $0.009 \%$ & .948 & $-0.173 \%$ & .249 \\
\hline \multicolumn{9}{|c|}{ Event Window $(-1,+1)$} \\
\hline 3 & $1.034 \%$ & $.003 * * *$ & $-0.412 \%$ & .479 & $1.095 \%$ & $.007 * * *$ & $-0.021 \%$ & .963 \\
\hline 2 & $0.798 \%$ & $.020 * *$ & $-0.488 \%$ & .415 & $0.909 \%$ & $.021 * *$ & $-0.182 \%$ & .697 \\
\hline 1 & $0.852 \%$ & $.010 * * *$ & $-0.119 \%$ & .826 & $0.942 \%$ & $.012 * *$ & $0.108 \%$ & .802 \\
\hline 0 & $0.679 \%$ & $.021 * *$ & $-0.274 \%$ & .554 & $0.950 \%$ & $.004 * * *$ & $-0.182 \%$ & .625 \\
\hline-1 & $0.374 \%$ & .125 & $-0.191 \%$ & .603 & $0.557 \%$ & $.050 * *$ & $-0.152 \%$ & .604 \\
\hline-2 & $0.169 \%$ & .379 & $-0.337 \%$ & .253 & $0.364 \%$ & .112 & $-0.324 \%$ & .163 \\
\hline-3 & $0.137 \%$ & .257 & $-0.178 \%$ & .379 & $0.255 \%$ & .083 & $-0.168 \%$ & .277 \\
\hline \multicolumn{9}{|c|}{ Event Window $(-1,+1)$} \\
\hline 1 & $0.709 \%$ & $.008 * * *$ & $0.235 \%$ & .588 & $0.658 \%$ & $.033 * *$ & $0.413 \%$ & .228 \\
\hline 0 & $0.555 \%$ & $.009 * * *$ & $-0.001 \%$ & .999 & $0.665 \%$ & $.005 * * *$ & $0.087 \%$ & .752 \\
\hline-1 & $0.175 \%$ & .133 & $0.085 \%$ & .695 & $0.193 \%$ & .133 & $0.099 \%$ & .559 \\
\hline
\end{tabular}

Note. *** Significant at $1 \%, * *$ Significant at $5 \%$. * Significant at $10 \%$.

Another very interesting analysis has been done in the above table, i.e. the impact of the dividend announcements on the returns of the large vs the small banks. Generally, in literature, there have been studies which show that size factor is significantly important for the returns, for example the FAMA three factor model, where it is clear that size impacts the payout policies too (Fama \& French, 2001), since there are both lifecycle as well as signalling implications for the small firms.

Lifecycle theory holds that small firms with greater growth opportunities may plough back more dividends and invest more in the positive NPV projects, even though there are signalling needs too, since the new small firms may be less credible in the market and to establish credibility they may pay stable dividends. However, this has a more direct correlation with the dividend life cycle theory rather than signalling, whereby, it is a 
well-documented fact that the large and matured firms suffer from the free cash flow problems. Hence, to solve this agency conflict it is rational for the managers to increase or maintain a steady dividend flow, and this is again responded to positively by the markets. These consequences are related to Foley et al. (2006) research in USA.

For the small and growing firms the problem is the opposite and they need to reinvest more in the good projects and pay fewer dividends. Accordingly, it's ploughing back of dividends which are responded to positively by the markets. However, it is doubtful whether banks can be interpreted in the same way or not, since the agency conflict in the case of banks is much more complicated since many parties are involved, namely depositors, shareholders, creditors, regulator and also the rest of society. Hence a simple life cycle theory won't be sufficient for explaining the dividend payouts by banks, and there is a gap in the current literature on the life cycle theory of banks (Grullon et al., 2002). Analogical results are shown in the above table.

The large banks are considered as those that have greater total assets than median or means, while the small banks have lower total assets than median or means. Importantly, the results of the table show that the CAAR for large banks are positive and significant, and small banks have insignificant negative CAAR. For example, for (-5, + ) window, the CAAR for large banks is $1.099 \%$ compared with $-0.302 \%$ for small banks (based on median), $1.034 \%$ vs. $-0.412 \%$ for $(-3,+3)$. These results show that the market optimism reacts to large banks' dividend more than small banks' dividend.

Banks do have other important factors impacting upon their payment policies, and one such factor is risk shifting. It is well documented that large banks continue paying large dividends even in times of crisis, and this is shifting wealth from depositors to shareholders. Hence, risk shifting is also an unobservable factor driving the dividend payouts of the above banks. There are moral hazard issues related to this trend, since given that there are safety nets for the banks they may continue shifting wealth to the shareholders by taking more risk, which may cause bank defaults or even systemic crisis.

\subsection{Impact of Financial Crisis on the DPS}

Financial crisis has provided good evidence about the risk taking and defaults of various big banks. Even during the crisis period the big banks have continued paying large dividends, and this point has been debated extensively (Kumar, 2009). The latest theoretical suggestion is that this phenomenon is equivalent to risk shifting in the sector. However, this theory is difficult to examine in reality since, as already shown, there are many factors affecting the level of payouts. Theoretical models too predict that banks which have greater default risk may gamble with depositor's money and pay large dividends to shift wealth towards shareholders, and this behavior is more pronounced when there are various types of implicit or explicit bail out guarantees, e.g. deposit insurance.

Table 5. Dividend per share for GCC banks

\begin{tabular}{ccccccc}
\hline DPS & Bahrain & Kuwait & Oman & Qatar & Saudi & UAE \\
\hline 2005 & .013 & .019 & .007 & .482 & .384 & .055 \\
2006 & .025 & .024 & .018 & .808 & .596 & .056 \\
2007 & .021 & .027 & .012 & 2.147 & .487 & .159 \\
2008 & .024 & .040 & .043 & 2.559 & .466 & .140 \\
2009 & .016 & .017 & .013 & 2.248 & .621 & .121 \\
2010 & .016 & .008 & .008 & 3.049 & .394 & .080 \\
2011 & .010 & .011 & .010 & 2.956 & .529 & .130 \\
2012 & .018 & .011 & .011 & 2.822 & .638 & .184 \\
2013 & .014 & .009 & .009 & 3.329 & .671 & .217 \\
\hline
\end{tabular}

Continuing with the above argument, the above table documents the dividend paying pattern for the banks in the midst of crisis, and as can be seen most of the large banks in the given economies have not stopped paying positive dividends in the time period; this may be related to signalling or even risk shifting. Another fact is that since these economies are less affected by the crisis in contrast to the developed markets, they could afford to remain consistent in their dividend pays (Hasan \& Dridi, 2010).

However, the trend has remained stable over the last decade, and after the end of the crisis the trend is still positive and upwards. There are industry life cycle models too which predict that an industry as a whole may be in a growth/maturity phase which further impacts the dividend payouts of the individual firms. This may well be the case for the banking industry as a whole for the given economies. 
Table 6. Number of payer and non-payer banks in GCC

\begin{tabular}{ccc}
\hline YEAR & No of Payer & No of None Payer \\
\hline 2005 & 49 & 5 \\
2006 & 41 & 9 \\
2007 & 44 & 7 \\
2008 & 52 & 8 \\
2009 & 36 & 6 \\
2010 & 35 & 23 \\
2011 & 44 & 15 \\
2012 & 42 & 10 \\
2013 & 47 & 7 \\
\hline
\end{tabular}

In the above table, there is a clear comparison between the payers and non-payers in the banking sector of these economies, and clearly the proportion of payers have increased over time; this may again be related to the lifecycle theory. There can be competitive pressure too, whereby many studies also show that dividends are influenced by degree of competition, and to keep up with the competitors' banks may be paying dividends steadily. Again, turning to the competitive atmosphere, the banking industries in these economies are dominated by a few large banks only, hence their market powers are considerable which is again reflected in the steady dividend payout policies.

For further explanation, the following charts will link the previous discussion with the GDP and the GCC stock markets index over the period 2005 to 2013:

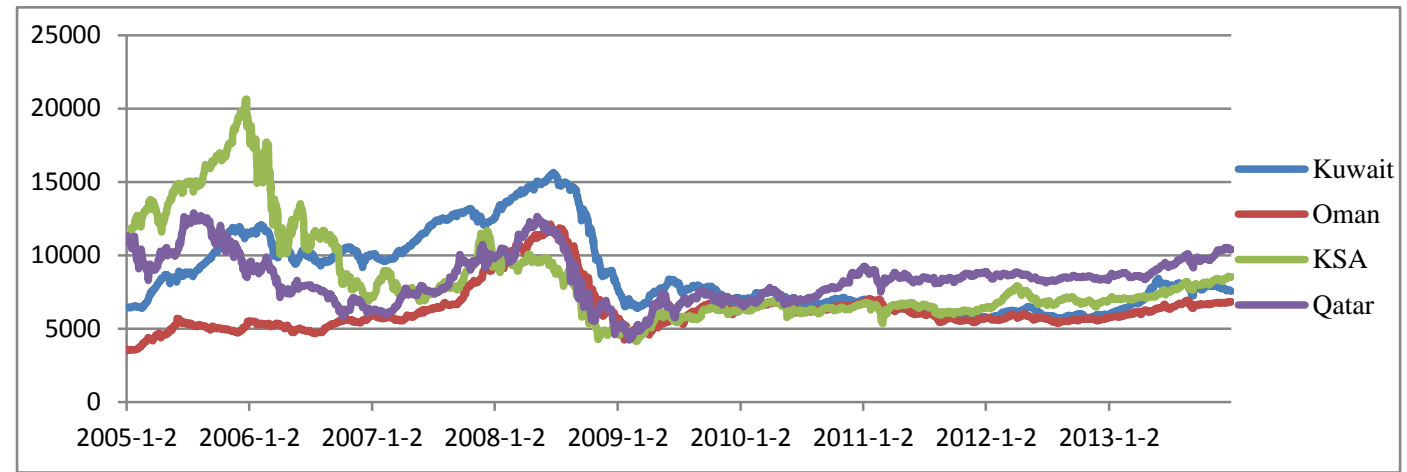

Figure 3. The stock market index 1

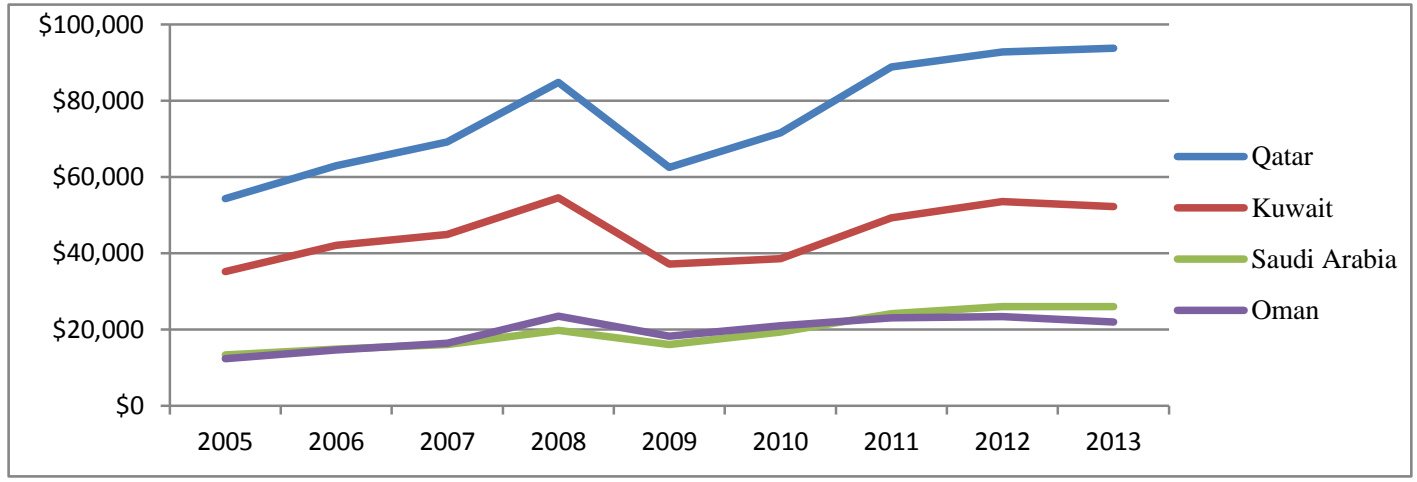

Figure 4. The GDP 1

The above two charts show the stock market index and GDP for (Kuwait, Oman, KSA, and Qatar). The indices for these countries was quite stable over the period of study, but as this paper discussed earlier, at the time of financial crisis between 2007 and 2009, the indices reported positive results. According to Gulf database and world development indicators (2015), that in 2008 the GCC economy achieved and reported an increase (surplus) in GDP by $7.6 \%$ compared to 2007 . This growth occurs during the high increase in oil production and prices. 
Besides that, there is an increase in non-oil revenues. This high revenue led to strong capital spending. Nevertheless, because of the global financial crisis and the slump of oil prices, the surplus of GDP dropped to 3.3\% in 2009. However, in 2010 and 2011 due to global recovery with the increase in oil demand; the prices of oil raised, which led to increase in revenues. Moving to UAE, the following charts show the stock market index and the GDP over the period 2005 to 2013.

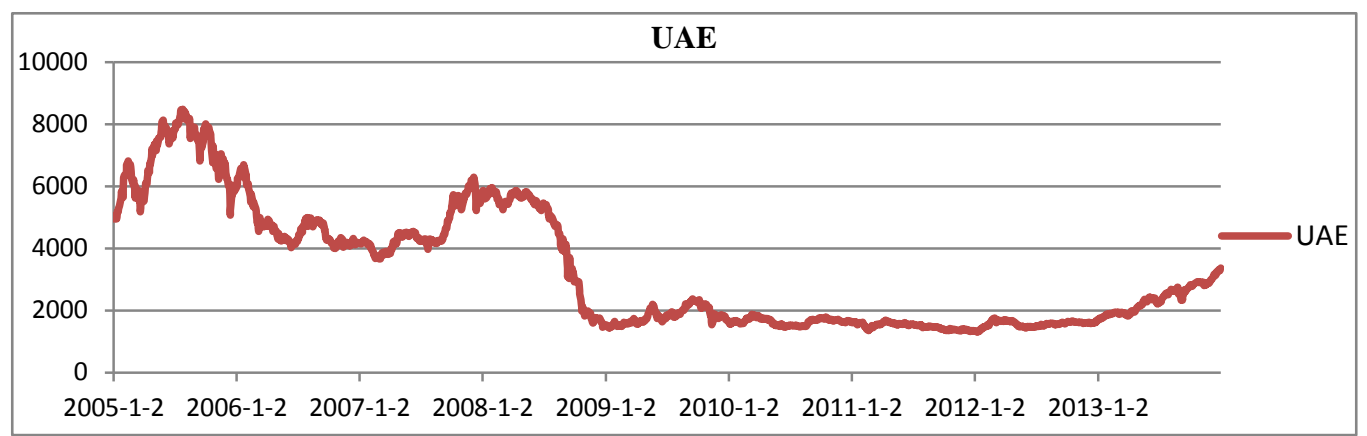

Figure 5. The stock market index 2

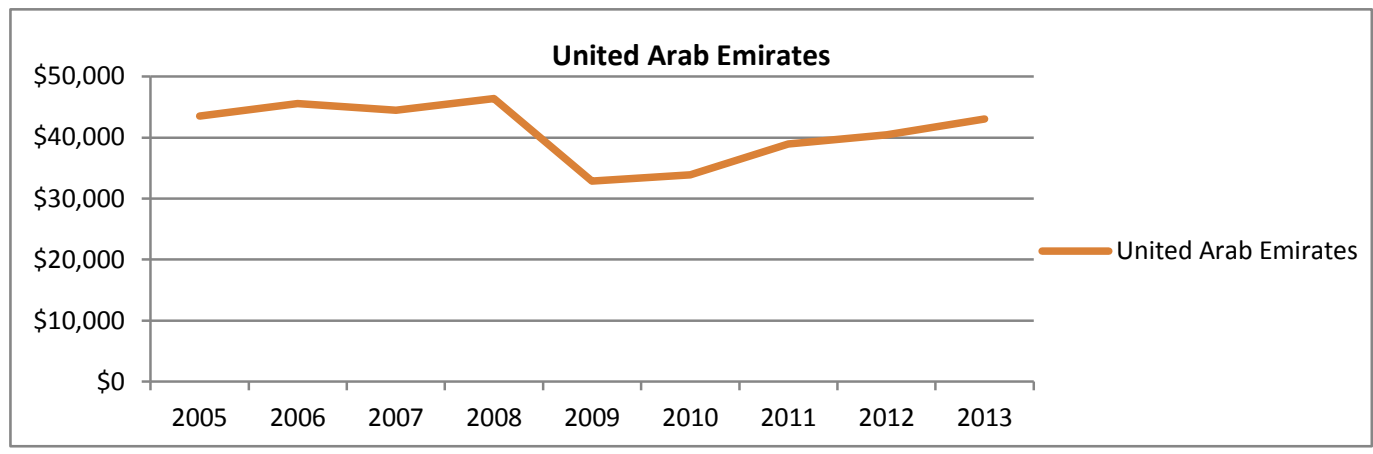

Figure 6. The GDP 2

The UAE is considered the second biggest economy after KSA in GCC countries. In addition, it achieved the highest rate in economic growth among all Arab regions. The reason behind that, the rapid increase in oil and gas exporting and the current economic diversification plans. According to Gulf database (2015) that in 2008, since the prices of oil increases, the oil production increases as well, and financial reforms have been taken in the economic, which reinforced the business confidence and economic growth in this country. In 2007 and 2008, the surpluses of budget on GDP were $26.7 \%$ to $12.4 \%$ respectively because of the increase in oil prices and exports. Nevertheless, because of the financial crisis and the oil prices slump, the surplus budget of GDP recorded $0.4 \%$ marginal rate. Therefore, the banking sector reported positive results, because it is protected by the economy, which is already supported by oil and gas industry. Nevertheless, even with the positive indicators during the financial crisis, the GCC banking sector affected by high inflation rates with the decrease in interest rate, which led to deep decline in real interest rates and incentives for saving (Abdelbaki, 2008).

\section{Research Findings and Empirical Implications}

The findings of the research provide significant results to investigate the unexplored issues in the dividend announcements for the GCC region. The results of analysis indicate that, for the short window $(-1,+1)$, the CAAR on the announcement day is positive $(0.328 \%)$ and significant at $10 \%$ level. In addition, the CAAR one day after the announcement is positive $(0.515 \%)$ and significant at $5 \%$ level. On the other hand, for the long window the CAARs are negative prior to the dividend announcements and steadily become positive after the announcements till the end of the window length $(-5,+5)$; this might indicate signalling which has to be tested further. However, the CAAR on the announcements day is positive $(0.229 \%)$, but insignificant. Therefore. Policymaker should consider that there is a strong signalling effect since most of the windows show positive impact of dividend announcements on the CAARS.

In addition, this study have tried to distinguish between payer and non-payer dividend, and the results show that that the CAARs are negative and significant for non-payer dividend (DPS=0). In addition, this result can be 
more interesting since the chosen sector is bank, and there are arguments for a higher opaque nature of banks. Hence, there might be more intense necessity for the banks to signal solvency via dividend payouts, and hence when they decide not to pay the market participants respond negatively.

Another important observation is that the negative impact of non-payer dividend is significant over all lengths of windows, whereas the positive affects fades with increase in the number of days. This again hints at the fact that investors consider 0 dividends/dividend cut as to be worse news than the increase in dividends; this behavior is again to be explained by other theories than signalling theory alone.

Moreover, the findings of the research showed that there is a clear negative significant impact on the CAARs for decrease in dividends, and positive impact for the increase in dividends. Comparing the impacts it is clear that decrease in dividends are taken as to be worse news than increase in dividends since the former impact is always more significant, and this can't be explained by signalling theory only as there can be various behavioral as well as life cycle factors motivating such results.

Another very interesting analysis has been done to examine the impact of the dividend announcements on the returns of the large vs the small banks. Generally, in literature, there have been studies which show that size factor is significantly important for the returns, for example the FAMA three factor model, where it is clear that size impacts the payout policies too (Fama \& French, 2001), since there are both lifecycle as well as signalling implications for the small firms. Lifecycle theory holds that small firms with greater growth opportunities may plough back more dividends and invest more in the positive NPV projects, even though there are signalling needs too, since the new small firms may be less credible in the market and to establish credibility they may pay stable dividends.

However, this has a more direct correlation with the dividend life cycle theory rather than signalling, whereby, it is a well-documented fact that the large and matured firms suffer from the free cash flow problems. For the small and growing firms the problem is the opposite and they need to reinvest more in the good projects and pay fewer dividends. Accordingly, it is ploughing back of dividends that are responded to positively by the markets. However, it is doubtful whether banks can be interpreted in the same way or not, since the agency conflict in the case of banks is much more complicated since many parties are involved, namely depositors, shareholders, creditors, regulator and also the rest of society. Hence, a simple life cycle theory will not be sufficient for explaining the dividend payouts by banks, and there is a gap in the current literature on the life cycle theory of banks.

Therefore, policymakers should consider this, since there can be equally significant lifecycle impact since the large banks show different payout pattern as compared with the small banks. In addition, this type of research has not previously received adequate investigation. Future research should pay further attention to the GCC region.

The large banks are considered as those that have greater total assets than median or means, while the small banks have lower total assets than median or means. Importantly, the results of the table show that the CAAR for large banks are positive and significant, and small banks have insignificant negative CAAR. For example, for (-5, + ) window, the CAAR for large banks is $1.099 \%$ compared with $-0.302 \%$ for small banks (based on median), $1.034 \%$ vs. $-0.412 \%$ for $(-3,+3)$. These results show that the market optimism reacts to large banks' dividend more than small banks' dividend. Consequently, Policymakers should consider that there can be equally significant lifecycle impact since the large banks show different payout pattern as compared with the small banks

The last result reported the impact of financial crisis on GCC countries. It linked the DPS with stock price indices and GDP of financial markets. The charts and tables show that the banking sector recorded positive results, because it is protected by the economy, which is already linked directly to the oil and gas industry. Importantly, Policymakers should consider this because banking industry in the GCC region is supported by oil prices and exports.

Importantly, most studies are concentrated on developed markets more than emerging markets, which are not probably examined, with the knowledge that there is massive potential in these areas to analyse the effect of dividend policy on shareholders. In addition, limited number of previous academic studies have discussed the whole Gulf area as one sample, the vast majority of researches being focused on specific countries. Therefore, this research has contributed to fill this gap in the literature and provided empirical implications to the policy makers.

However, in this kind of research, the restrictions are usually linked to the time and the availability of data, because of these constrains support the analysis to be more efficient. However, there are some available 
evaluations which may be indicated, such as; a) utilizing logistic regression models; this may support in examining the dividend policies of the banks with additional information when the dependent variable is acting for the possibility of dividend payment, and the independent variables are varying in the life cycle. b) Structural break examination could be in a position to check if the CAR responses have improved essentially over the period, specifically pre and post financial crisis and c) the study may utilize several methodologies to create more explanation and analysis for study such as the CAPM model.

\section{References}

Ariss, R. T. (2010). On the implications of market power in banking: Evidence from developing countries. Journal of Banking and Finance, 765-775. https://doi.org/10.1016/j.jbankfin.2009.09.004

Asimakopoulos, G., Brissimis, S., \& Delis, M. (2008). Efficiency in the Greek banking system and its determinant factors. Economic Bulletin, 30, 7-34.

Ball, R., \& Kothari, S. (1991). Security returns around earnings announcements. The Accounting Review, 66, 718-738. Retrieved from https://www.jstor.org/stable/248152?seq=1\#page_scan_tab_contents

Barnea, A., Haugen, R., \& Senbet, L. (1981). An Equilibrium Analysis of Debt Financing Under Costly Tax Arbitrage and Agency Problems. The Journal of Finance, 36, 569-581. https://doi.org/10.1111/j.1540-6261.1981.tb00645.x

Bhattacharya, S. (1979). Imperfect Information, Dividend Policy and the "Bird-in-Hand" fallacy. The Bell Journal of Economics, 10, 259-270. https://doi.org/10.2307/3003330

Brennan, M. (1970). Taxes, Market Valuation and Corporate Financial Policy. National Tax Journal, 414-427.

Brennan, M. J., \& Thakor, A. V. (1990). Shareholder preferences and dividend policy. Journal of Finance, 45, 993-1018. https://doi.org/10.1111/j.1540-6261.1990.tb02424.x

Chaplinsky, S., \& Seyhun, H. (1990). Dividends and taxes: Evidence on tax-reduction strategies. The Journal of Business, 63, 239-261. https://doi.org/10.1086/296504

Chemmanur, T., He, S., \& Hu, G. (2010). The role of institutional investors in seasoned equity offerings. Journal of Financial Economics, 94, 384-411. https://doi.org/10.1016/j.jfineco.2008.12.011

Dasilas, A., Lyroudi, K., \& Ginoglou, D. (2008). Joint effects of interim dividends and earnings announcements in Greece. Studies in Economics and Finance, 25, 212-232. https://doi.org/10.1108/10867370810918128

DeAngelo, H., \& Masulis, R. W. (1980). Leverage and dividend irrelevancy under corporate and personal taxation. Journal of Finance, 35, 453-464. https://doi.org/10.1111/j.1540-6261.1980.tb02176.x

Dewi, C. (2011). Stock Market Reaction to Dividend Announcement in Indonesian Listed Companies. Master's thesis, Universiti Utara Malaysia

Fama, E. F., \& French, K. R. (2001). Disappearing dividends: Changing firm characteristics or lower propensity to pay. Journal of Financial Economics, 60, 3-43. https://doi.org/10.1016/S0304-405X(01)00038-1

Foley, F., Hartzell, J., Titman, S., \& Twite, G. (2007). Why do Firms Hold so Much Cash? A Tax-Based Explanation. Journal of Financial Economics, 86, 579-607. https://doi.org/10.1016/j.jfineco.2006.11.006

Gordon, M. (1959). Dividends, Earnings and Stock Prices. Review of Economics and Statistics, 41(2), 99-105. https://doi.org/10.2307/1927792

Grullon, G., Michaely, R., \& Swaminathan, B. (2002). Are dividend changes a sign of firm maturity? Journal of Business, 75, 387-424. https://doi.org/10.1086/339889

Hasan, M., \& Dridi, J. (2010). The Effects of the Global Crisis on Islamic and Conventional Banks: A Comparative Study. Working Paper, 10(201), International Monetary Fund, Washington, DC: U.S. Retrieved from https://www.imf.org/external/pubs/ft/wp/2010/wp10201.pdf

Hussainey, K., \& Walker, M. (2009). The effects of voluntary disclosure and dividend propensity on prices leading earnings. Accounting and Business Research, 39(1), 37. https://doi.org/10.1080/00014788.2009.9663348

Hussainey, K., Mgbame, C., \& Chijoke-Mgbame, A. (2011). Dividend policy and Share Price Volatility: Uk Evidence. Journal of Risk Finance, 12(1), 57-68. https://doi.org/10.1108/15265941111100076

Iqbal, N., Ahmad, N., Ullah, H., \& Abbas, A. (2014). Effect of dividend announcement on stock prices in banking industry of Pakistan. International Letters of Social and Humanistic Sciences, 35, 15-25. https://doi.org/10.18052/www.scipress.com/ILSHS.35.15 
Iqbal, T. (2007). Market Reaction to Earning Information: An Empirical Study. AIMS International, 1(2), 153-167.

Jais, M., Bakri, K., Funaoka, K., \& Azlan, A. (2010). Dividend Announcements and Stock Market Reaction. MPRA ,19779(12).

Jensen, M., \& Meckling, W. (1978). Can the Corporation Survive? Financial Analysts Journal. https://doi.org/10.2469/faj.v34.n1.31

Kumar, P., \& Tsetsekos, G. (1999). The Differentiation of 'Emerging' Equity Markets. Applied Financial Economics, 9, 443-453. https://doi.org/10.1080/096031099332104

Kurniasih, A., Siregar, H., Sembel, R., \& Achsani, N. A. (2011). Corporate Dividend Policy in an Emerging Market: Evidence from Indonesia Stock Exchange (IDX) 2001-2008. International Research Journal of Finance and Economics, 72.

Lang, H., \& Litzenberger, R. (1989). Dividend announcements: Cash flow signaling vs free cash flow hypothesis. Journal of Financial Economics, 24, 181-191. https://doi.org/10.1016/0304-405X(89)90077-9

Lintner, J. (1956). Distribution of Incomes of Corporations among Dividends, retained Earnings and Taxes. American Economic Review, 46(2), 97-133.

Manneh, M., \& Naser, K. (2015). Determinants of Corporate Dividends Policy: Evidence from an Emerging

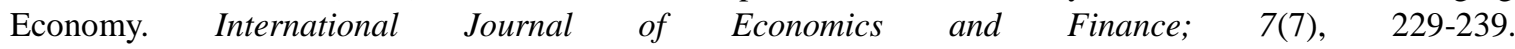
https://doi.org/10.5539/ijef.v7n7p229

Michaely, R., Thaler, R., \& Womack, K. (1995). Price reactions to dividend initiations and omissions: Overreaction or drift? Journal of Finance, 50, 573-608. https://doi.org/10.1111/j.1540-6261.1995.tb04796.x

Miller, M. H., \& Modigliani, F. (1961). Dividend Policy, Growth and the valuation of Shares. Journal of Business, 34, 411-33. https://doi.org/10.1086/294442

Miller, M. H., \& Scholes, M. S. (1982). Dividends and taxes: some empirical evidence. Journal of Political Economy, 90, 1118-1141. https://doi.org/10.1086/261114

Miller, M., \& Rock, K. (1985). Dividend Policy under Asymmetric Information, Journal of Finance, 40, 1031-1051. https://doi.org/10.1111/j.1540-6261.1985.tb02362.x

Modigliani, F., \& Miller, M. (1958). The Cost of Capital, Corporation Finance and the Theory of Investment. The American Economic Review, 48, 261-297.

Petit, R. (1972). Dividend announcements, security performance and capital market efficiency. Journal of Finance, 27, 993-1007. https://doi.org/10.1111/j.1540-6261.1972.tb03018.x

Ryan, A., Besley, C., \& Lee, H. (2000). An Empirical research of reaction to policy changes for NASDAQ companies. Journal of Financial and Strategic Decisions, 13(1).

Shleifer, A., \& Robert, V. W. (1986). Large Shareholders and Corporate Control. Journal of Political Economy, 94(3), 461-88. https://doi.org/10.1086/261385

Sterk, \& Vandenberg. (1990). The Market Valuation of Cash Dividends and the Tax Differential Theory of Dividend Policy: A Case Revisited. Financial Review, 25(3), 441-455. https://doi.org/10.1111/j.1540-6288.1990.tb00806.x

Taneem, S., \& Yuce, A. (2011). Information Content of Dividend Announcements: An Investigation of the Indian Stock Market. International Business and Economics Research Journal, 10(5), 49-57. https://doi.org/10.19030/iber.v10i5.4230

Uddin, M., \& Osman, D. (2008). Effect of dividend announcement on shareholders' value: Evidence from Saudi Arabian stock exchange. The International Journal of Business and Finance Research.

Walter, J. E. (1956). Dividend Polices and Common Stock Prices. The Journal of Finance, 16, 29-41. https://doi.org/10.1111/j.1540-6261.1956.tb00684.x

\section{Copyrights}

Copyright for this article is retained by the author(s), with first publication rights granted to the journal.

This is an open-access article distributed under the terms and conditions of the Creative Commons Attribution license (http://creativecommons.org/licenses/by/4.0/). 